\title{
Developing E-Module Inquiry Based Website of Gasoline Motor Technology at Second Semester of Automotive Education Department of Universitas Muhammadiyah Purworejo
}

\author{
${ }^{1 s t}$ Dwi Jatmoko \\ Program Studi Pendidikan Teknik Otomotif \\ Fakultas Keguruan dan Ilmu Pendidikan Universitas \\ Muhammadiyah Purworejo \\ dwijatmoko@umpwr.ac.id;
}

\author{
2) Aci Primartadi \\ Program Studi Pendidikan Teknik Otomotif \\ Fakultas Keguruan dan Ilmu Pendidikan Universitas \\ Muhammadiyah Purworejo \\ aci@umpwr.ac.id
}

\begin{abstract}
The purpose of this study is to develop e-module learning media with inquiry based website in the subject of gasoline motor technology of automotive education program at Universitas Muhammadiyah Purworejo. The subjects of the study were the second semester students of Automotive Education, Universitas Muhammadiyah Purworejo. This study was conducted in the Automotive Engineering Education Study Program of the Teaching and Education Faculty using research and development ( $R \& D$ ) methods. The stages in this study consist of: (1) needs analysis, (2) learning design development, (3) product design development, (4) initial product evaluation, (5) implementation and evaluation. The validation process was carried out by 1 material expert and 1 media expert. Forum Group Discussion (FGD) was held for product implementation and learning design. The trial subjects consist of $\mathbf{4 0}$ students consisting of: 10 students for small group trials, and $\mathbf{3 0}$ students for large group trials. Data collection is done using a questionnaire. The results of the study show that: (a) in general the quality of the material validated by material experts is valid; (b) the quality of the media that is validated by media experts is valid; (c) the results of the trial is categorized as very good, in which all aspects show good assessment, including teaching methods, use of learning media, material or teaching materials, time utilization, student behavior, learning facilities; (d) e-module products on the website are effectively used for courses in the Learning of Gasoline Motor Technology in a very feasible category. In addition, data from observations and interviews indicate that the developed gasoline motor technology e-module products are able to motivate student learning, improve retention, and improve self-study skills.
\end{abstract}

Key Words: E-modules, Websites, Inquiry Learning, Gasoline Motor Technology

\section{INTRODUCTION}

The development of technology and information is so rapid today. The development and changes of human civilization will continue. The demands of professional services in various sectors of life are increasingly deep and the quality of human resources that meet the expectations of society is increasingly needed. The description of the future society can be described with characteristics such as: the trend of globalization, the development of science, and technology that is increasingly fast, the development of increasingly dense information flows, and the demands of professional services in various sectors of life. Improving the quality of human resources needs to be prepared early to deal with the demands of changing times. The problem that is now faced by many countries including Indonesia is how to improve the quality of education, which is generally associated with high and low levels of achievement indicated by the ability of students to get grades in the test and the ability of graduates to get a job. Improving the quality of human resources will be realized if placing education as a means of encouragement and educational tools will have meaning and goals in increasing resources if the education has a system that is relevant to development and good quality in the process and results. In improving the quality of education needs to be supported by the renewal in the field of education. One way is through improving the quality of learning, namely by updating the approach or increasing the relevance of teaching methods. The teaching method is said to be relevant if in the process it is able to deliver students to achieve educational goals through learning but in reality there are still many teachers who teach monotone that is only using one method. Therefore, it is necessary to develop teaching methods that make students more active in the teaching and learning process and in accordance with the learning of gasoline motor technology. The cause of the disturbance or obstacle in students learning gasoline motor technology because of the view that gasoline motor technology is an elusive subject. This assumption can weaken the enthusiasm of student 
learning so students will become lazy and dislike the gasoline motorbike technology course.

Media development in the learning process is one of the efforts to improve the quality of the learning process, which in turn can improve the quality of student learning outcomes (Azhar Arsyad, 2012: 15). One of the learning media that can be used is computers as media based on information and communication technology. Computers can be used as a tool in preparing teaching materials and in the learning process to be more effective and efficient. Computer software used in the development of learning media is Portable Document Format (Electronic Module / E-Module) based on websites. This program can display information in the form of writing material, gasoline motorbike work practice steps, and 2D component images, as well as interesting animations on the website that are published online (Website), so that students can be more interested in participating in gasoline motorbike technology courses. Based on the description above, the authors are interested in conducting research on the development of e-module learning media with a website-based inquiry approach in the subject of gasoline motor technology at Universitas Muhammadiyah Purworejo in the automotive engineering education program.

\section{DISCUSSION}

Development of E-Module Learning Gasoline Motor Technology that is carried out in accordance with the R and D development stage, which includes 5 stage, analysis, planning, product development, implementation and evaluation. The analysis phase used is needs analysis and material analysis. From the results of the needs analysis, learning of gasoline motor technology that uses learning media is still minimal, which is usually done by teaching staff only instructional assignments to students. Another aspect that is in the knowledge of students is still lacking and students still do not have an overview of the work steps in the sequence when working on the practice of Gasoline Motor Technology. It can be concluded that students do not understand the Operational Standards for gasoline motorbike practical work.

The results of the material analysis, obtained the data that the gasoline motor material is one of the material which is considered to be fundamental which is quite difficult for students because students have not been able to understand the concepts contained in gasoline motor technology material. At the planning stage, the Gasoline Motor Learning E-Module was made by looking at references to the Toyota book manual and directly pouring module scripts in the word office. After that the document is exported or made in the form of Adobe Acrobat Document (.pdf) files so that they can be easily viewed on all computers and can also be uploaded on the website.
The next stage is product development carried out in the media validation stage by media and material experts. As well as responses to student response sheets in small group tests. In the implementation phase, the student's assessment phase of the website-based emodule is carried out with the inquiry learning method. The last is a large group test or evaluation stage which aims to measure the validity and effectiveness of the developed learning media.

Development of e-module gasoline motorbike learning media is raised from the problem that students feel confused about what they want to do so that when taught using guided inquiry methods using modules, students can actively work on practical tasks, besides that students can also know the steps and operational standards for workshops. The choice of e-modules as learning media is done because there is a tendency for students to buy books or prefer to have guidelines or practice guidelines. And also obtained data from the analysis conducted that most students have Android phones. So it is expected that with the gasoline motorbike technology module material that is input into the website, students at any time want to learn gasoline motorbike practice material by reading on their respective mobile phones and students feel happy and accustomed to the gasoline motor technology module in which there is a standard work standard. It is expected that in addition to learning gasoline motor technology using this e-module students also learn and read article articles in cyberspace or the internet. As well as the selection of modules in the form of electronic or entered online network based on modern times, students prefer reading reading on mobile phones compared to reading books. Besides that, students choose e-module because it is cheaper and more practical if downloading e-module compared to buying a manual book and is more practical when it will be taken and read wherever it is. Stored on a mobile phone or in a flashdisk e-module can be brought wherever students travel.

Learning media for e-module gasoline motor technology is said to be valid / valid, assessment data from media experts, material experts, and cultural experts state that the media is "valid" criteria. With an average score of $75 \%$ from material experts who stated that the media was feasible, and from media experts to obtain data with an average score of $73.33 \%$, media experts said the media was valid or worthy of use. And from both media and material experts if averaged to get an average percentage score of $74.16 \%$. Based on the assessment of material experts and the media it can be concluded that the medium of gasoline motor technology e-module is valid. The assessment is seen from the aspects of presentation, pictures and writing, content or content, language and application in learning. Learning media e-module gasoline motor technology is said to be effective, if material experts and media experts state that the media can be properly 
used with little revision or without revision. In this study, material experts stated that the media can be used with revision, with input plus steps to check procedures on cooling water and oil checks. For media experts stated that the media can be used properly with revision, by making the website color contrast and writing made official and normal fonts. Based on the results of this study, e-module gasoline motor technology is categorized as effective. The e-module learning media for gasoline motorbike technology is said to be effective (Nana Sudjana and Ahmad Rifai (2014) based on the criteria of media accuracy responses, teaching methods, use in learning, material / content, time, student behavior, and infrastructure facilities. Before being tested first, the FGD was conducted to plan the implementation of the inquiry method and obtained a draft design and teaching method.On the pilot practice of gasoline motor technology students' response data in the small group test got a score of $82.4 \%$ with very decent criteria with a total of 10 students and to test large groups get a percentage score of $85.6 \%$ with very decent criteria with the number of respondents 30 students.

Student assessment results in large group test or final stage test on e-module gasoline motor technology learning are effective criteria or there are positive differences if using e-module with normality test data get a sig value of 0.769 so that if the sig value $>0.05 \%$ then the data is concluded normal. Furthermore, from this study, the results of one sample t-test are t-count 194.042 and sig value. (2-tailed) 0,000. So it can be concluded that if $\mathrm{t}$-hit $>\mathrm{t}$-table then there is a difference or with this media there is an increase in the effectiveness of TMB practices. The $t$ count value is $194.042>2.042$ and the sig value is smaller than $0.05 \%$, which is $0.000<0.05 \%$. From the two data above, it can be concluded that the e-module learning media for gasoline motorbike technology learning is effective. The development of e-module learning gasoline motor technology is said to be feasible based on valid, and effective criteria. From the results of the research described in the previous point, it can be concluded that the e-module of gasoline motorbike learning technology meets the criteria of valid, and effective. So the e-module of gasoline motorbike technology learning is "eligible" to be used as a learning media for gasoline motor technology.

\section{CONCLUSION}

Starting from the needs and material analysis, it is known that students need a learning guide on the practice of gasoline motor technology which is a basic material which is considered quite difficult, then developed e-module gasoline motor technology which contains the operational standard of the workshop work, after that the e-module is validated by material experts, material experts and focus group discussions and small and large group trials. Based on the results of the study, e-module splitting meets valid criteria obtained from the mean percentage of material expert scores by $75 \%$, and media experts $73.3 \%$, and obtained an average of two media experts by $74 \%$. So that it is concluded that it meets the criteria valid or worthy of use. Furthermore, to fulfill the criteria of effectiveness, it was shown based on the responses of students in the small group test to get a score of 82.42 and a large group test with a mean percentage of $85.6 \%$. Besides that e-module learning gasoline motor technology got a positive response by testing the normality of getting sig values. 0.659 in the Kolmogorov-Smirnov test and is greater than the sig value. $0.05 \%$. As well as the t-test (one sample t-test), the t-count value is 194.042> 2.042 and the sig value. $0.00<0.05 \%$ so it was concluded that with this learning media there was a positive difference or increased effectiveness of practical learning in gasoline motorbike courses.

\section{REFERENCES}

Arikunto (2011) Prosedur Penelitian. Jakarta: Rineka Cipta.

Arsyad, Ashar. (2012). Media Pembelajaran. Jakarta: PT.

RajaGrafindo Persada

Pavlov, I. P. (1902). The Work of the Digestive Glands. London: Charles Griffin, 1902, hal. 23-33

Sugiyono. (2010). Metode Penelitian Pendidikan (Pendekatan Kuantitatif, Kualitatif dan R\&D). Bandung: Alfa Beta.

Sudjana. (2010) Metode Statistik. Bandung: PT. Tarsito Sujana, N dan Rivai. (2014). Media Pengajaran (Penggunaan dan Pembuatannya). Bandung: Sinar Baru Algesindo 